\title{
INSTITUTIONAL ORGANIZATION OF CONSUMER CREDIT
}

\author{
M. R. NeIrelD*
}

It is a sociological truism that social institutions come into being and develop in response to social stimuli, and the many forms in which consumer credit is offered in modern society is an illustration of this truism. A complex social and economic structure elicits a variety of consumer credit institutions, the character, structure and function of which are conditioned by the legal, economic and social forces at work in the milieu in which they originate.

So it was in antiquity and so it is true today. Under the realistic compulsion of business needs, usury legislation over the ages, passed from complete condemnation to reluctant acceptance of the economic justification for interest as a charge for the use of money or credit. Finally, in the reign of Henry VIII, the canonical laws in England against usury gave way to temporal legislation in which a quantitative line of demarcation was drawn between legal and illegal transactions which set a numerical pattern followed by usury legislation in the American colonies.

Although the new legal distinction between interest and usury simplified business negotiations, it left unsolved the difficulties of consumer credit. Mechanization, industrialization and urbanization transformed the structure of society and raised to the proportion of a major social problem, protection for the needy borrower against his own ignorance and the pressure of his need. To save the wage earner from too harsh a bargain in which he must pay unconscionable charges for his credit, became an important goal of social action.

Distinctly different conditions in England and in the United States led to characteristically nationalistic treatments and consequences in the placing of limitations on the charges for borrówing money. There came a parting of the ways when England in 1854 repealed the Usury Act of Queen Anne, while usury legislation in the United States continued to impose a statutory maximum rate of interest. ${ }^{1}$ From there on, the development of usury regulation in the two countries followed divergent paths. Curiously though, the divergent paths led to equivalent destinations; and a recent change in the English viewpoint has emphasized still more the identity of the goal. Petitions to the chancery courts of England for aid against oppression slowly

- A.B., 1913, Cornell University; M.A., 1916, Columbia University; Ph.D., 1922, New York University. Economist, Beneficial Management Corporation. Author, The Personal Finance Business (I933), Cooperative Consumer Credit (1936), Personal Finance Conses of Age (1939), and other publications.

${ }^{1}$ See Horack, $A$ Survey of the General Usury Laws, infra p. 36. 
forced on the parliamentary lawgivers the conviction that small borrowers needed special legislative relief from harsh and unconscionable money bargains into which they had been forced by the exigencies of their needs. In the courts of equity, the contracts could be examined, the agreements weighed in the light of all the circumstances; and the contracts remade, when necessary, on more appropriate terms.

In the absence of a legal maximum rate as an arbitrary guide, the courts were compelled to subject each case to individual consideration. There was no yardstick by which to measure legal usury, but a facile principle of justice to both parties of the contract came to guide the decisions. Eventually, this principle was condensed into the British Money-Lenders Act of $1900,{ }^{2}$ which spelled out and added to the powers of the chancery courts. Since no quantitative standard was inserted in the law, it continued to be the duty of the court to decide for itself when a loan rate ceased to be fair and just.

From the beginning, the quantitative rather than the qualitative test for usury has ruled in the United States. With a few specific exceptions such as the stock market call money rate, the proscription of corporations to plead usury and the absence of statutory maximums in a few states, there has been no general deviation from the principle patterned after the earlier English usury statutes of the late seventeenth and early eighteenth centuries. With these exceptions, the state legislatures of the United States have not been able to divorce themselves from the conception of a mathematical limit which effortlessly divides the socially desirable from the undesirable. However, the usury statutes drew no distinction between business transactions and the small loan needs of wage earner and clerical worker, although the financial needs of the consumer were of a higher order of costs than those of the businessman.

As long as the economic organization of the early United States was simple, application of the usury statutes to the consumer in search of credit caused no hardships; but toward the end of the nineteenth century industrial development in the United States had progressed to the point where the wage earner appeared in numbers large enough to, create new social problems. These changing conditions made credit for the wage earner in small amounts more and more necessary, but since the insecurity of his job made him a doubtful risk and the size of his loans was more costly to handle than the larger commercial loans, the usury statutes made it unprofitable for the banker to deal with him. In times of need the wage earner did not brook the cost; he looked for credit where he could find it. In response to his demand a supply appeared in the form of lenders who were willing to disregard the prohibitions of the usury statutes for the sake of profit, but because these lenders were outside the pale of the law, the price they asked took into account the risk of social ostracism and legal conviction. And thus was born in this country the problem of loan sharks, "high-raters" or illegal lenders; a problem which was not solved reasonably well until enlightened students of social conditions subjected it to objective survey.

These surveys revealed that the evils which beset money lending in small sums

$263 \& 64$ Vict., c. 5 I. 
were products of uneconomic restrictions rather than consequences of the money lending function itself. The wage earner had legitimate need for borrowing, but as the loans made to him were riskier and costlier than those made to business, it was unprofitable for the banker to engage in consumer financing. The field of serving the consumer was open to anyone who would defy the usury statute for the sake of profit. The loan shark is not the cause but the product of a social condition. Earliei attempts to cope with small loan abuses had led to the establishment of the Provident Loan or Remedial Loan Associations, but the experience of these philanthropic or semi-philanthropic institutions soon demonstrated that the social problem was too immense for philanthropic control. It could be met only on a commercial basis. The solution of the social abuses of the loan shark had to be an economic one.

When this fact became clear, three solutions were offered simultaneously. Each solution sought to leap over the restrictions of the usury laws. Still, true to their American heritage, the solutions cling to a quantitative measure, but the figure set depends on the type of institution created by the solution. A plan of advancing consumer credit along the lines of traditional banking usage gave rise to the industrial banks of the Morris Plan type. A second plan, by introducing the new principle of cooperative banking, led to the creation of credit unions. And a third plan, for commercial operation on a truly adequate scale, brought into being personal finance companies. Each of these solutions required new type legislation under which the institutions could have legal sanction to assess against the wage earner the costs of the credit service which were higher than the rate set in the usury statute.

The Morris Plan or industrial bank was based on the structure of commercial banks, but modified the traditional lending practice by introducing indirect instalment repayment of the loan. By combining the sale of security on the instalment basis with the making of a loan, a procedure was developed which has the practical result of increasing the lender's income above the stated rate. This is effected by selling the, borrower an investment certificate to be paid off by a series of equal payments spaced periodically over the life of the loan. As the face amount of the certificate is equal to the loan, the security, when fully repaid, can be used to liquidate the loan at maturity. Certificates are also sold as genuine investment securities without relation to loans, and thus yield working capital for these institutions. In effect, Morris Plan companies met the demand for consumer credit by adjusting existing financial institutions to the wage earners' needs.

While the Morris Plan preserved at least the traditional form of banking, the credit union broke away altogether, in form as well as in fact, from the long tradition of the usury statute. Since pioneer days neighborly self-help has had an honorable ancestry in the United States and credit unions have organized the principle of selfhelp to cut the cost of consumer credit below commercial rates. The credit union looks to the wage earners to furnish their own credit from their own capital. A group of wage earners bound together by a common racial, religious or vocational tie unite. 
to form a common pool of funds built up from weekly contributions. Members borrow from the common fund when they are in need and repay in instalments.

It is a curious fact that the most effective challenge to the loan-shark evil was offered neither by the tinker refashioning existing institutions nor by the idealist preaching the gospel of mutuality, but by students of social conditions who in this field made two outstanding contributions to social progress. They accepted as a fact the economic basis of the need for cash credit by wage earner and clerical worker in a money economy, and they recognized that it was of a magnitude which could be handled only on a commercial scale. When these two premises were accepted it became easy to formulate legislation which would attract capital in the vast quantity required. The studies were made by the Russell Sage Foundation which was largely responsible for the drafting of the so-called Uniform Small Loan Law. ${ }^{3}$ This model statute is revised from time to time to keep it abreast of changing conditions. It contains stringent provisions for regulation and supervision of the consumer finance agencies licensed under the act; limits the maximum loan usually to $\$ 300$; and permits a maximum rate designed to permit a fair and reasonable profit above the high costs of making small loans. The passage of the Uniform Small Loan Law and its retention on the statute books has been over the bitter opposition of the loan sharks who have obstructed it at every opportunity.

While the United States were severally awakening to the existence of the sinall loan problem, and were, through the Uniform Small Loan Law and other statutes, moving to legislative acceptance of maximum rates high enough to attract capital in sufficient amounts to meet the demand, England was revising her experience with the Money-Lenders Act of Igoo. After having parted company with American practice in 1854 , and after having had almost three decades of trial under the liberal act of rgoo, England partly retraced her path by the new British Money-Lenders Act of 1927. This, however, was no turn-about. All the important elements of the older act were retained, but there was added to them a quantitative standard for detecting usury. The new law allows a rate of $4 \%$ per month. The maximum monthly rate under the American Uniform Small Loan Law was initially $3 \frac{1}{2} \%$ per month; now the rates in effect average less than $3 \%$.

The outstanding difference in the way the two laws treat this quantitative gauge reflects the different conceptions of usury present in the two countries. In the United States the $3 \frac{1}{2} \%$ is a statutory maximum. No exception is permitted. Under the English approach, the $4 \%$ monthly rate is merely a convenient separation of the unquestionable from the deals where the burden of proof is shifted to the lender. In a particular set of circumstances, it is conceivable that a monthly rate on small loans of $5 \%$ or more may be entirely proper and fair; but in all cases in excess of $4 \%$, the presumption is that the interest charged is excessive and the transaction "harsh and unconscionable" unless otherwise proved. The English have applied the inverse

\footnotetext{
see Hubachek, The Development of Regulatory Small Loan Laws, infra p. xo8.
}

' 17 \& 18 GEO. V, C. 21 . 
equivalent of our "innocent until proved guilty" criminal court procedure. When the rate exceeds $4 \%$, the presumption is usury until differently proved, and the burden of proving the contrary is on the lender.

The British Money-Lenders Act of 1927 is significant for American experience because it confirms the solution offered for the usury problem by the Uniform Small Loan Law. England has not abandoned the qualitative approach, but it has narrowed the field in which the qualitative test must be applied. And that narrowing of the field has been brought about by the adoption of a quantitative guidepost to be used as a first rough approximation. By adding the use of a preliminary quantitative test, England has adopted the method all along used by the United States; but it has avoided the rigidity of our $3 \frac{1}{2} \%$ maximum. At one and the same time, she has reduced the pressure of cases on the courts and yet has retained the elastic interpretation of usury.

One other essential difference exists. In the American statute, the rate is a monthly one and must be so expressed; although, as the Uniform Small Loan Law specifically forbids compounding of interest, the annual rate is the simple product of 12 times the monthly rate. Under the English statute, there is no set way required for stating the rate, and the emphasis is on $48 \%$ a year rather than on $4 \%$ a month. Judicial interpretations of the variety of contracts that have come before the English courts have gradually led to a standardization of the method of computing the rate, and the courts generally follow the same formula. ${ }^{5}$ While more inflexible, the American method has the advantage of being simpler, more readily understood by the borrower and more easily administered.

So here we have laid clearly before us the background of consumer credit development in the United States. Emotional and social prejudices clustering about the concept of interest clashed with a changing economic framework in which legal restrictions developed through a long course of trials and errors for one purpose, were causing trouble when applied to another. But, in addition to the agencies which were developed to meet the cash needs of the wage earner, other institutions came to the fore to help him, when he did not have on hand the large amount of cash necessary to acquire them, secure for his use the conveniences and luxuries which industry was offering invitingly. The purchase of books, sewing machines and jewelry, for a long time, had been offered on weekly payments spread over many months, but instalment financing as an important element in our financial mechanism came into widespread use only with the advent of the motor car. And with that occurrence instalment selling mounted out of the disreputable to become the means of acquiring semi-durable goods, acceptable to all income levels of the population. In fact, it is hard to disentangle from the marvelous improvement in automobile efficiency the part played by consumer finance and the part played by the wonderful advance in engineering which has made the motor car an instrument of universal use.

The rise in real wages after the World War had given the industrial worker a

- Thorp, Watson and Wilson, The Law of Money Lending (London, 1928). 
larger margin of income above subsistence needs than ever before. Available for what has been called "high level" consumption, this margin is expended on conveniences and luxuries in the form of semi-durable equipment which industry turns out in bewildering variety to compete for the family dollar; but as the cost of these goods is generally in excess of the free margin from current pay envelopes, either they must be paid for by drafts on savings reserves or they must be financed through mortgages on future free margin income. This margin the wage earner uses to purchase enormous quantities of household equipment financed through sales finance companies, through banks and through retail merchants themselves.

When the unemployment of the depression resulted in a tremendous drop in sales volume, the merchants of the country turned seriously to the use of credit to bolster their sales volume. Sales appeal to lower and lower income levels spread from the smallest to the biggest retailer and from so-called durable or repossessable goods to soft goods which had no repossessable value. At the same time government agencies, such as the FHA and EFHA, came into being and lent more than three quarters of a billion dollars in loans to modernize real estate, and to buy electrical household equipment.

Credit is offered by retailers either in the form of open account or in the form of various budget, deferred income or instalment plans. The difference between open account and instalment credit lies in the formal nature in which the debt is acknowledged by the consumer. Evidence of indebtedness on open charge accounts is informal. It is usually a ledger account posted from sales checks written at the point of sale by the sales clerk in the ordinary course of business. The sales checks may or may not be signed by the customer. Security for indebtedness on charge accounts is the credit reputation of the purchaser, his implied promise to pay, and his past payment record. Bills are mailed monthly and are due the month following the purchase, or from 30 to 60 days after purchase.

In contrast to the informal nature of open account credit, the instalment credit transaction is a more formal affair. ${ }^{6}$ Evidence of the debt is a signed instrument called a note and a title instrument reserving title or a claim on the merchandise until the deferred balance is paid. Sometimes the two are combined in the same paper and called a lease contract or conditional bill of sale. The instruments describe the merchandise in the transaction and the terms on which it will be paid. Instalment credit defers payments over an agreed number of weeks or months, but calls for regular payments of agreed amounts. The cost of the credit is called a financing or carrying charge. In addition to the credit worthiness of the purchaser the extension of instalment credit is protected against loss by the resale of merchandise repossessed for failure to complete the instalment contract.

The retailer may finance his own instalment paper or he may sell it to a bank or a sales finance company. If he finances his own paper he holds the note and title instrument in his own possession and records the periodical payments as made.

- Sec (1935) 2 Law \& Contemap. Prob. No. 2 (entire issue). 
When the final payment is made he stamps the note and title instrument as paid and returns them to the buyer. Department stores, retailers of agricultural instruments, pianos, sewing machines, books, furniture and jewelry generally borrow on their own general credit, but carry their own instalment receivables.

Since financing his own instalment receivables freezes a merchant's working capital, he frequently secures cash by selling his signed instruments of indebtedness to a bank or a sales finance company. The sale is made at a flat price which is at a discount from the face amount of the note. Sometimes he sells "without recourse," and sometimes "with recourse" by endorsing or guaranteeing the instruments he sells. If the deal with the finance company is without the right to recourse, the retailer is released from liability as an endorser; if it is with recourse, the paper on which collection difficulty arises is turned back to the dealer without loss to the sales finance company or bank. Another common variation is a repurchase agreement between finance agency and dealer under which the dealer, to avoid separate endorsement of individual notes, agrees to repurchase any merchandise collateral repossessed by the sales finance company within a given period.

Instead of selling his instalment receivables, a dealer may finance himself by hypothecating with a finance company or a bank, instalment notes or conditional sales contracts as a pledge to secure his own note for a loan. Under the agreement which accompanies such transactions, the right is reserved to withdraw satisfied or defaulted notes and substitute others. Under the indirect payment arrangement, the merchant continues to collect from his customers, but pays the full amount or a pre-arranged portion to the finance company or the bank to reduce his own loan balance. Finance companies in their relations with banks use this device of pledging but not selling their holdings. A trustee is sometimes designated to hold and to supervise the paper for the protection of all creditors pro rata.

In addition to the credit advanced directly to consumers by retailers and by specialized cash lending agencies, commercial banks have recently come into the field. Many banks have no formal personal loan department, but the number which have established special departments to handle consumer finance is increasing rapidly. Mention must also be made of the credit extended to consumers by the service group of creditors which include members of the curative professions, healing institutions, funeral directors and other personal service purveyors.

Having briefly described the background of the social and economic forces which historically shaped the different types of consumer finance organizations it is now time to turn to a more detailed description of the extent and scope of the sources of small loan credit.

Retail sales ebb and flow with changes in the national income; and the total consumer debt, as would be expected, fluctuates closely with the total of retail sales in the United States. In the II years which stretch between I929 and I939, consumer credit has fluctuated between a low of $\$ 4,000,000,000$ and a high of more than $\$ 8,000$,000,000 . These amounts, which represent the magnitude of the unpaid claims on 
consumers' incomes, are receivables outstanding at year ends. The volume of credit transactions throughout the year is, of course, much larger than the amount of receivables at the year end.

\section{TABLE I}

Estimated Total Consumer Debt in the United States, 1929-19397

Open-account and instalment, incurred by the purchase of consumer goods and services on credit, financed by the retailer or by banks and finance companies.

\begin{tabular}{|c|c|c|}
\hline Year & $\begin{array}{c}\text { Amount } \\
\text { (millions) }\end{array}$ & $\begin{array}{l}\text { Percent of } \\
1929\end{array}$ \\
\hline rg29... & $\$ 8,142$ & 100.0 \\
\hline 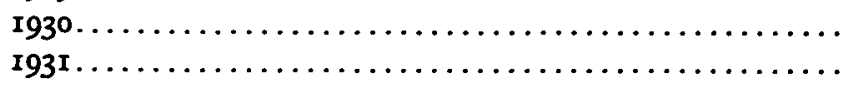 & $\begin{array}{l}7,400 \\
6,370\end{array}$ & $\begin{array}{l}90.9 \\
78.2\end{array}$ \\
\hline 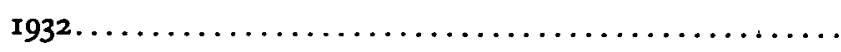 & 4,723 & 58.0 \\
\hline 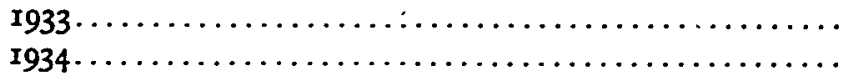 & $\begin{array}{l}4,437 \\
3,982\end{array}$ & $\begin{array}{l}54.5 \\
61.2\end{array}$ \\
\hline 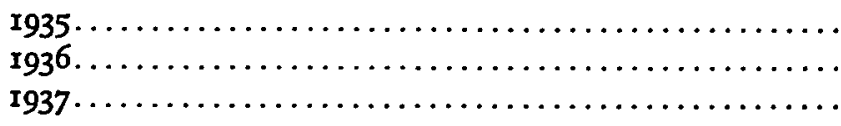 & $\begin{array}{l}5,860 \\
7,275 \\
8,125\end{array}$ & $\begin{array}{l}72.0 \\
89.4 \\
99.8\end{array}$ \\
\hline 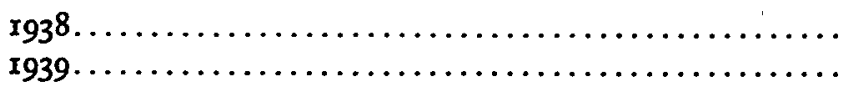 & $\begin{array}{l}7,400 \\
8,065\end{array}$ & $\begin{array}{l}90.9 \\
99.1\end{array}$ \\
\hline
\end{tabular}

Some students are much exercised over this enormous fluctuation. They profess to see in it a case of the tail wagging the dog. Contractions and expansions of consumer credit exert powerful, dampening and expansive pressures which are magnified several times in their final effect on the economy; and these effects exaggerate the

TABLE II

\begin{tabular}{|c|c|c|c|c|c|c|c|}
\hline \multicolumn{8}{|c|}{ Retail Sales iN the UNITED States, I929-1939 } \\
\hline & $\begin{array}{c}\text { Total } \\
\text { Sales } \\
\text { (millions) }\end{array}$ & $\begin{array}{c}\text { Open Account } \\
\text { Sales } \\
\text { (millions) }\end{array}$ & $\begin{array}{l}\text { Per } \\
\text { cent }\end{array}$ & $\begin{array}{c}\text { Instal- } \\
\text { ment Sales } \\
\text { (millions) }\end{array}$ & $\begin{array}{l}\text { Per } \\
\text { sent }\end{array}$ & $\begin{array}{c}\text { Cash } \\
\text { Sales } \\
\text { (millions) }\end{array}$ & $\begin{array}{l}\text { Per } \\
\text { cent }\end{array}$ \\
\hline $\begin{array}{l}929^{2} . \\
933^{2} .\end{array}$ & $\begin{array}{r}\$ 49, \mathrm{II} 5 \\
25,037\end{array}$ & $\$ r 0,290$ & $\begin{array}{l}2 \mathrm{r} \cdot 3 \\
(6,944\end{array}$ & $\begin{array}{l}\$ 6,500^{\mathrm{c}} \\
27.7 \%)^{\mathrm{a}}\end{array}$ & 13.0 & $\begin{array}{r}\$ 32,325 \\
18,093\end{array}$ & $\begin{array}{l}65.7 \\
72.3\end{array}$ \\
\hline $35^{2}$. & 33,011 & 7,041 & 21.3 & 3,599 & ro.9 & $22,37 x$ & 67.8 \\
\hline $26^{b}$ & $37,94^{\circ}$ & $8, \mathrm{r} 60$ & 21.5 & $4,4^{89}$ & Ir.8 & $25,29 \mathrm{r}$ & 6.7 \\
\hline $37^{\circ}$ & $39,93^{\circ}$ & 8,828 & 22.1 & 4,627 & Ir.6 & 26,475 & 6.3 \\
\hline & 35,425 & 7,921 & 22.4 & 3,309 & $9 \cdot 3$ & 24,105 & 68.3 \\
\hline
\end{tabular}

a. From Retail Census. b. Estimate of Bureau of Forcign and Domestic Commerce. c. Instalment sales proportion for 1929 based on 5-state sample applied to United States totals. d. For 1933 the open-account and instalment proportions are not available separately.

${ }^{7}$ Sternberg, Indebtedness in the United States, 1929-39 (June I940) 20 SuRvey CuR. Bus. No. 6, p. 12 and Table $\mathbf{r}$ at p. 15. This periodical is published by the Bureau of Foreign and Domestic Commerce, U. S. Dep't Com.

- Rezall Installment Paper Held by Banks (June 1940) 26 Fed. Res. Buxx. 526. Nat. Ass'n Sales Finance Cos., Annual Releases, Composite Experience of Sales Finance Companies and Auto Dealers. For abstracts of these two items, sea U. S. Dep't Com., Business Information Service. See also Sales-Finance Companies and Banks' Hoidings of Retail Instalment Paper (U. S. Dep't Com., 1940). From these references, the material in Table III and footnotes $10,11,13,14,15,16,17,18,19,20$ and 23 following, are also adapted. 
ceilings and the troughs of the business cycle. Consequently, proposals have been advanced to regulate, by manipulation of changes in the liberalization of credit terms, through central banking techniques, the insertion of consumer credit into the economy at moments when it will be most beneficial to the general welfare.

Two trends in the development of the financial mechanism of the country emphasized the importance of further study in this field. Although the total consumer debt in the years 1929 and r939 was about the same, the character of the debt had changed. In the later year cash lenders were more important quantitatively than in the earlier year. Furthermore, consumer debt had increased in importance in relation to the loan portfolios of all banks in the country. Commercial bank loans amounted to $\$ 42,000,000,000$ in 1929 but dropped to $\$ 22,000,000,000$ in 1939 . Relative to these

\section{TABLE III}

Approximate Consumer Instalment Indebtedness in the United States, 1938-t939 (Except Indebtedness to Retailers)

\begin{tabular}{ccc}
$\begin{array}{c}\text { Paper pur- } \\
\text { chased or }\end{array}$ & \multicolumn{2}{c}{ Amount of Paper or Loans } \\
amount loaned & Outstanding at End of Year \\
during 1939 & 1939 & \multicolumn{2}{c}{1938} \\
(add ooo) & (add ooo) & (add ooo)
\end{tabular}

Sales Finance:

Agency or lender

Sales finance companies $\ldots \ldots . \quad 2,584$

Insured commercial banks $\ldots$ ro, $38 \mathrm{r}$

Personal Finance:

Other industrial banking

companies"

Personal finance comanies $\ldots$....

Personal finance companies" ${ }^{c}$.

Personal loan departments of commercial banks ${ }^{a}$

Cooperative credit unions ${ }^{2} \ldots \ldots, \quad 8,500$

Pawnbrokers

$\begin{array}{r}231 \\ 4,036 \\ 3,000 \\ 8,500 \\ 1,500 \\ \hline 30,196\end{array}$

$\$ 1,990,283$
750,000

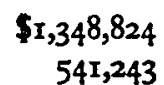

$\$ 1,143,728$

$35^{0}, 000^{\circ}$

Total............... 30,196

$\begin{array}{r}432,400 \\ 757,300 \\ 592,000^{\circ} \\ 279,000^{=} \\ 200,000^{8} \\ \hline 5,000,983\end{array}$

219,176

409,700

207,830

$34^{8,000^{\circ}}$

$$
\begin{aligned}
& 3 \times 0,000^{\circ} \quad 248,000^{\circ} \\
& 146,000^{\circ} \quad \text { II } 3,000^{\circ} \\
& 93,000^{\circ} \quad 95,000^{\circ} \\
& \$ 3,067,943
\end{aligned}
$$

2. Retail Installment Paper Held by Banks, supra note 8; see also other references in that note.

b. Table 35, Industrial Banking Companies-Instalment Loans (Sept. 1940) 20 SuRvey CuR. Bus., No. 9, at 18: since September $194^{\circ}$ carried as an item in the Monthly Statistical Tables. Loans and holdings as shown therein, less $\$ 37,424,000$ of time sales paper duplicated in above holdings of sales finance companies and banks.

c. Personal Finance Companies-Instalment Loans to Consumers (Credit Analysis Unit, Marketing Research Div., U. S. Dep't Com., r940). Rolf Nugent, Director, Department of Consumer Studies of the Russell Sage Foundation, estimates $\$ 395,000,000$ at the end of 1939 and $\$ 348,000,000$ at the end of 1938 .

d. Chapman and Associates, Commercial Banks and Consumer Instatment Crepit (Nat. Bur, Econ. Res. I940).

c. Russell Ságe Foundation (mss. 1940). Prepared especially for this report through the courtesy of Rolf Nugent. Figures for 1939 are preliminary.

f. American Association of Personal Finance Companies. Latest available count.

g. Estimated in the absence of available data. Last 3 items in second column based primarily upon 2verage ratio of $\mathrm{I.9I}$ to I between loans and outstandings in 96I banks with personal loan departments.

\footnotetext{
- Exclusive of home mortgage debt (owner-occupied premises), mortgage debt on income property business and investment debt, and indebtedness to retailers.
} 
amounts, the total of consumer debt had practically doubled. Many cross currents of change contributed to this result.

As retail sales ebb and flow, about two thirds are always sold for cash and one third on credit. Sales on credit are divided between open account and instalment in the ratio of about two to one. Of these, the open account sales form somewhat more than one fifth of total retail sales and instalment transactions about one tenth. Instalment sales vary more than do either cash or open account sales. The figures on retail sales are assembled in Table II, page 30.

A bird's-eye picture of merchandise and cash credit instalment indebtedness in the United States is set forth in Table III, page 3r.

A brief explanation will help to interpret this important table which summarizes the consumer instalment debt of the United States, except that owed directly to merchants, to service creditors, and to friends and relatives. The amount of retail instalment paper reported as purchased by sales finance companies may include finance charges and insurance as well as the unpaid balance of the purchase price of the merchandise. Finance charges include interest, costs of acquisition, collection and administration, provision for losses, taxes and business profit. Sales-finance paper charges, in the case of automobile paper, average 15 to $18 \%$ or more of the face value of the note, ${ }^{10}$ of which about one half (about $8 \%$ of the face of the note) is for fire, theft, and collision insurance for the joint protection of debtor and creditor. About one sixth ${ }^{11}$ is set aside for dealer loss reserve or loss bonus, payable to the dealer gradually over the life of the paper. About one third is the actual finance charge for the company. Some companies permit dealers to add a "pack" or flat additional bonus which is paid to the dealer in cash, without disclosing the facts to the debtor. Insur. ance is seldom charged to the purchaser (debtor) except in automotive financing, but in the latter it is a substantial source of income of finance companies, who receive in commissions about one third of the amount of the premium..$^{12}$ Insurance against loss by fire, theft and property damage is more important in automobile than in other transactions, and hence, the face value of automotive paper generally includes the cost of insurance to protect both debtor and creditor.

During 1939, almost $\$ 2,000,000,000$ of retail instalment paper arising from the sale to consumers of motor vehicles, household appliances, oil burners, radios, furniture, and other merchandise was purchased by sales finance companies. At the year end these companies held approximately $\$ \mathbf{1}, 350,000,000$ of such paper. Purchases during the year were approximately one and one half times the total investment in such paper at the end of the year. Most of the purchases of sales-finance companies are from retailers, who accept the paper from customers in the form of instalment notes

\footnotetext{
${ }^{20}$ The proportions used in this paragraph are based upon an analysis of 147,095 notes (average face value $\$ 388$ ) of $\mathrm{r}_{4}$ companies in 1937 , made by the National Bureau of Economic Research. See Plummex and Young, Sales Finance Coupantes and Thimir Credit Practices (Nat. Bur. Econ. Res., 1940).

${ }^{11}$ See Fed. Trade Com., Report on Motor Vehide Industry, H. R. Doc. No. 468, 76th Cong., ist Sess. (1939) 937-1058.

${ }^{1 .}$ See note 8 supra.
} 
or conditional sales contracts secured by purchase-money liens on the merchandise bought on deferred payments.

Sales-finance companies secure much of their working capital through heavy borrowings at the banks. Since $1934^{13}$ banks have flocked into the sales-finance field in large numbers and are competing for large quantities of retail instalment paper directly from dealers or to a smaller extent through paper-purchasing companies. At the end of I939 bank holdings of this class of paper totaled over $\$ 540,000,000^{14}$ or $28.6 \%$ of the combined holdings of banks and sales-finance companies. Of the 13,493 insured commercial banks in the country ro,381 reported that they handled retail instalment paper.

Attracted by the higher return in retail instalment paper compared to the lower return obtainable on wholesale loans to finance companies, the banks, about r939, themselves began to buy and hold retail instalment paper. Some banks are handicapped in the sales-finance field because of their unwillingness to go along with unethical trade practices. Banks generally refuse to load the finance charge with excessive loss reserves for the benefit of dealers or to "pack" the amount of the note with charges above the regular finance cost. Floor planning or "wholesaling" is a necessary corollary without which many automobile, electric-appliance and oil-burner dealers cannot exist. Dealers expect the finance companies who purchase their retail instalment paper to lend them working capital at a low rate of interest and to carry their floor stocks, demonstrators, and trade-ins. Most dealers are unable to qualify for straight bank loans, and banks with few exceptions lack the trained personnel and facilities for handling and safeg:arding the more hazardous loans which salesfinance companies have learned to make with reasonable safety. Consequently, most banks find they can do business only with a small group of dealers. They are finding more possibilities for investment of funds in so-called direct sales financing, in which the bank lends the money directly to the consumer-purchaser who buys for cash from the dealer.

Cash instalment loans are offered by personal loan departments of banks, credit unions, industrial banking companies, personal finance companies, pawnbrokers, unregulated lenders, and a scattering of other institutions.

Industrial banks combine three distinct fields of financing-sales finance, cash

28 "Banks became interested in the remarkable safety and high return of retail instaiment paper as a result of their favorable experience with sales-finance companies during the depression years. Experimentally during 1934 and aggressively since 1936 , many banks entered the field as a means of employing idle funds. Leading sales-finance company executives state that bank competition has not been destructive in breaking down terms or lengthening the instalment period, but criticise the willingness of many banks to lend their names to advertising which misrepresents the cost by failing to distinguish clearly between discount and interest. They further urge banks not to gage the business by three good years during which prices of new and used cars have been stable and abandonments rare, pointing to the need of good dealer connections as outlets for used cars and the value of repurchase agreements in years when used-car prices fall precipitately." Sales-Finance Companies and Banks' Holdings of Retail Instalment Paper, supra note 8 , at p. 7 .

14 "About one-third of sales-finance paper handled by banks is created by loans for purchase of cars or other definite commodity purchases-two-thirds is papes bought from dealers." $\mathrm{K}$. R. Cravens, vicepresident, Cleveland Trust Co. Id. at 7n. 
loans, and business loans. The first Morris Plan company was organized in Norfolk, Virginia, in I9ro. At the I939 year end, industrial banks including Morris Plan banks and companies held about $\$ 37,500,000$ of retail instalment paper (net of hypothecated deposits). These holdings indicate purchases of paper during I 939 of approximately $\$ 56,000,000$.

The Bureau of Foreign and Domestic Commerce reports $23 \mathrm{I}$ industrial and Morris Plan banks with additional purchases in 1939 of about $\$ 432,400,000^{16}$ and holdings of \$219,176,000 ${ }^{16}$ which, for the purposes of this summary, may be considered primarily personal-loan business. Industrial banks make consumer loans to \$5,000 and more. They usually discount their borrowers' notes, at 5 to $8 \%$, which is equivalent to an effective rate of about twice as much or more. In some areas their discount rates are higher; frequently investigation fees and charges are added.

Personal finance companies, date from I9rr-15 during which period six states legalized them under varying small loan acts. Some 30 states have passed small loan legislation modelled on the Uniform Small Loan Act drafted by the Russell Sage Foundation. Personal finance companies are restricted to maximum cash loans of \$300. Outside endorsers are seldom required, but in most instances loans are made solely on the signature of the borrower. The spouse of the borrower usually joins in the contract to make the obligation a family matter. Chattel mortgages are often required but seldom enforced. Wage assignments, once a common form of security, are disappearing from use. Interest is not deducted from the amount borrowed, nor does the face value or principal amount of the note as reported include interest. Interest is computed on the unpaid principal balance and diminishes in amount with each payment of principal. The small loan rate varies in the different states from 2 to $3 \frac{1}{2} \%$ per month payable on the unpaid balance. Operating expenses average about $18 \%$, of which one third is payroll. Bad-debt losses of principal from I929 through 1937 have ranged from $1.1 \%$ to $4.3 \%$ of the amount loaned. A substantial portion of the loans made by licensees under the small loan act are for the purpose of paying past-due debts, and to that extent they do not create additional debt.

The 4,036 offices of personal finance companies loaned $\$ 757,200,000$ during r939 and had total outstandings at the end of that year of $\$ 409,700,0000^{17}$ The totals include new loans to present borrowers as well as loans to new borrowers.

According to the National Bureau of Economic Research at least $1,500^{18}$ commercial banks have established personal loan departments to finance the consumer

${ }^{15}$ Table 35, Industrial Banking Companies-Instalment Loans (Sept. I940) 20 Survey Cur. Bus,, No. 9 , p. 18 .

18 As an indicator of the nature of this business, the Bureau of the Census is advised that the amount of the average loan made by all Morris Plan banks and companies in 1939 was approximately $\$ 255$.

${ }^{17}$ Personal Finance Companies-Instalment Loans to Consumers, supra note c (Table' III). Sec also Neifetd, Personal. Finance Cones op Age (1939) for a record of the development and growth of this business.

1" Chapman and Associntes, Cojomercial Banzs and Constmer Instalment Credit (Nat. But, Econ. Res. 1940). Including branches, the number probably approaches 3,000. K. R. Cravens estimates the present number of banks with small loan departments at 2,500 to 3,000. Sales Finance Companies and Benks' Holdings of Retail Instalment Paper, supra note 8, at 38n. 
directly. Loans average about $\$ 220^{10}$ and are secured by merchandise already owned or by endorsement of comaker. Banks ordinarily discount borrowers' notes at $4 \frac{1 / 3}{3}$ to $6 \%$ or at an effective interest rate of 8 to $12 \%$ per year. Additional revenue is obtained by some banks through "service" charges and late charges. Many banks require borrowers to provide life insurance for the bank's protection. The volume of consumer business by banks in 1939 is estimated at $\$ 592,000,000$ and net holdings of such paper at the end of $x 939$ at $\$ 310,000,000 . .^{20}$

Federal credit unions and those established under state laws are about 8,500 in number. The usual interest is $1 \%$ per month on the unpaid balance, equivalent to simple interest at the rate of $12 \%$. It is estimated ${ }^{21}$ that they loaned over $\$ 279,000,000$ and that their outstandings at the year end totaled $\$ 146,000,000$. The first credit union was organized in Igog. The business is almost entirely cash lending, not sales finance.

Remedial loan associations, are historically significant in the development of cash lending agencies, but statistically insignificant. They operate in only $2 \mathrm{I}$ cities and originally semi-philanthropic in nature with low interest rates, now are little different from small loan companies. The term referred to institutions which impose a limitation on dividends of $6 \%$, but while some still keep their rates down to 9 or $12 \%$ per year; others now exceed these rates, lend on chattels in the manner of pawnbrokers, and are included with them.

At the end of 1939 , pawnbrokers had about $\$ 93,000,000$ of pledge loans outstanding. The usual rate of interest varies from 2 to $3 \%$ to $10 \%$ per month. The outstandings of these lenders on pledges indicate an annual volume of about $\$ 200,000,000$.

Estimates for the amount of business done by illegal loan sharks and for the amount of informal lending by relatives, friends, employers, and the like, are not included in the summary of Table III. Receivables of unregulated lenders are estimated to be about $\$ 100,000,000$ with a volume of six or seven times as much.

Aside from an undetermined balance of accounts receivable on the books of retailers and of unpaid billings on the books of service creditors, ${ }^{22}$ the estimates point to a figure in excess of $\$ 1,000,000,000$ of consumer cash indebtedness outstanding; in addition there is about $\$ 1,900,000,000$ of sales finance paper in the hands of finance companies and banks. ${ }^{23}$

\footnotetext{
${ }^{20}$ Comaker notes $\$ 217$; secured loans $\$ 255$ to $\$ 274$; single loans $\$ 200$. Chapman and Associates, op. cit. supra note 18 .

${ }^{20}$ Growth of personal loan departments since 1936, based upon loan balances of 55 representative banks compiled by the Consumer Credit Department of the American Bankers Association is shown by the following range of numbers: End of 1936, 100; June 1937, 139; Dec. 1937, 161; June 1938, 165; Dec. 1938, I72; June I939, I89; Dec. I939, 205; June 1940, 247.

${ }^{21}$ These estimates from Table III overstate the facts. Federal credit unions in operation at the end of September, 1940, numbered 3,699, in addition to 4,250 state credit unions in 1938 . Loan volume in 1939 was $\$ 7 \mathrm{r}, 000,000$ for federal and $\$ 135,000,000$ for state credit unions. See Operations of Credit Unions, 1939 (Sept. 1940) 51 MONTHLY LaB. REv. 654 .

${ }_{22}$ Estimated to be $\$ 557,000,000$ in 1937. Nugent, Consumer Credit and Economic Stability (Russell Sage Foundation, 1939).

${ }^{25}$ Retail Credit Survey, 1939 (U. S. Domestic Com. Series, Marketing Res. Div.) will provide a measure of open-account credit and instalment notes on the books of retailers as of the end of r939.
} 